\title{
Tungau Debu Rumah dan Faktor Risiko yang Terkait Pada Rumah Siswa SDN 001 Buluh Cina Kabupaten Kampar Provinsi Riau
}

\author{
Muhammad Kurnia Caesar ${ }^{*}$, Lilly Haslinda ${ }^{2}$
}

\begin{abstract}
House dust mites (HDM) are organism which may be found in people's houses around the world. House dust mites can live optimally in the house with humidity above $70 \%$. This study aimed to find out the proportion and risk factors of HDM, and also the relationship in the student's houses of SDN 001 Buluh Cina, Kampar District, Riau Province. This study was an analytical study with cross sectional design and quota sampling method with 70 respondents. Dust samples were collected from bed, sofa/chair, floor, carpet, and ventilation of student's houses. The data used in this study and transported for direct microscopic examination of the dust. The data on risk factors obtained from questionnaire. Based on microscopic examination, proportion of HDM positive in this study was $47,1 \%$. Risk factors analysis showed that most respondents have private house status $(82,9 \%)$, good interpretation of frequency of cleaning the bed $(54,3 \%)$ and area of ventilation $(80 \%)$, ceramic floor type $(68,5 \%)$, and synthetic bed type $(78,5 \%)$. Analysis of the relationship between the presence of HDM and risk factors showed that there was a significance difference between risk factor type of bed with the presence of $\operatorname{HDM}(\mathrm{p}<0,05)$.
\end{abstract}

Keywords: house dust mites, humidity, SDN 001 Buluh Cina, proportion, environmental factor

Tungau debu rumah (TDR) adalah makhluk hidup yang berukuran sangat kecil namun berperan penting dalam menimbulkan penyakit alergi seperti dermatitis atopik, asma dan rinitis alergi. Spesies TDR yang paling sering menyebabkan penyakit alergi adalah Dermatophagoides pteronyssinus dan Dermatophagoides farinae. Spesies TDR ini mampu merangsang reaksi hipersensitivitas dalam tubuh sehingga menimbulkan gejala penyakit alergi. ${ }^{1}$ Menurut data World Health Organization (WHO), hingga tahun 2018 prevalensi TDR di seluruh dunia mencapai $27,5 \%$ dengan prevalensi tertinggi berada di Benua Eropa $(32,9 \%)$ dan Asia $(30,7 \%){ }^{2}$ Survei lainnya yang juga dilakukan oleh

Penulis korespondensi: kurniacaesar30@gmail.com

${ }^{1}$ Fakultas Kedokteran Universitas Riau, Pekanbaru, Riau, Indonesia

${ }^{2}$ KJF Parasitologi Fakultas Kedokteran Universitas Riau, Pekanbaru, Riau, Indonesia
Kemenkes RI menunjukkan bahwa rasio positif TDR di Provinsi Riau sebesar 42,3\%. ${ }^{3}$ Sementara itu, laporan data prevalensi TDR oleh Dinas Kesehatan (Dinkes) Provinsi Riau tahun 2014 pada rumah siswa SD di Kabupaten Kampar sebesar $52,3 \%{ }^{4}$

Keberadaan TDR dipengaruhi oleh beberapa faktor seperti status rumah, luas ventilasi rumah, dan jenis lantai rumah. Penelitian yang dilakukan oleh Widiastuti ${ }^{5}$ di Pamulang, Tangerang menunjukkan bahwa sebagian besar responden dengan rumah kontrakan tidak ditemukan TDR di dalam rumah. Hal tersebut dikarenakan keberadaan TDR dipengaruhi oleh perpindahan penghuni rumah. Luas ventilasi yang minim akan menyebabkan terganggunya pertukaran udara dan masuknya cahaya matahari ke dalam rumah. Hal tersebut akan menyebabkan peningkatan kelembapan udara yang cocok bagi perkembangbiakan TDR. $^{6}$ Penelitian yang dilakukan oleh Howieson menyebutkan bahwa sebagian besar rumah responden dengan luas ventilasi $<10 \%$ dari luas lantai rumah ditemukan TDR di dalam rumah. ${ }^{7}$ Jenis lantai rumah juga 
dapat mempengaruhi keberadaan TDR di dalam rumah. Jenis lantai keramik akan menyerap kalor lebih baik sehingga menyebabkan ruangan menjadi lembap dan cocok bagi perkembangbiakan TDR. ${ }^{8}$ Faktor yang juga dapat mempengaruhi keberadaan TDR adalah jenis tempat tidur dan frekuensi membersihkan tempat tidur. ${ }^{9}$ Jenis tempat tidur berbahan alami menjadi tempat yang cocok bagi perkembangbiakan TDR. Penelitian yang dilakukan oleh Regina di Manado menunjukkan bahwa sebagian besar penduduk yang menggunakan tempat tidur berbahan alami yaitu kasur kapuk ditemukan TDR di dalam rumah. ${ }^{10}$ Frekuensi membersihkan tempat tidur juga dapat mempengaruhi keberadaan TDR, menurut penelitian yang dilakukan oleh Rambing menyebutkan bahwa sebagian besar responden yang rutin membersihkan tempat tidur, tidak ditemukan TDR di dalam rumah. ${ }^{11}$

Dinas Kesehatan Kabupaten Kampar menyebutkan Kabupaten Kampar memiliki prevalensi penyakit alergi sebesar $9,3 \% .^{12}$ Sementara itu, survei yang dilakukan oleh Dinas Kesehatan Provinsi Riau menyebutkan bahwa proporsi TDR di rumah siswa SDN 001 Buluh Cina sebesar 40,3\%. ${ }^{13}$ Berdasarkan latar belakang tersebut, maka peneliti tertarik untuk melakukan penelitian tentang proporsi TDR dan faktor risiko pada rumah siswa SDN 001 Buluh Cina, Kecamatan Siak Hulu, Kabupaten Kampar, Provinsi Riau.

\section{METODE}

Penelitian ini merupakan penelitian analitik dengan desain cross sectional. Pada penelitian ini dilakukan pemeriksaan debu untuk mengetahui keberadaan TDR dan pengisian kuesioner untuk melihat faktor risiko TDR pada rumah siswa. Populasi dari penelitian ini adalah seluruh siswa SDN 001 Buluh Cina, Kabupaten Kampar, Provinsi Riau. Sampel dari penelitian ini adalah siswa yang memenuhi kriteria inklusi yaitu, siswa yang hadir saat penjelasan, orang tua yang mengisi kuesioner dan siswa yang mengumpulkan plastik debu. Pengambilan sampel telah ditentukan sebanyak 70 orang sesuai metode quota sampling. Sampel debu yang dikumpulkan pada penelitian ini berasal dari tempat tidur, sofa/kursi, karpet dan ventilasi pada rumah siswa serta masing-masing diberi kode yang ditentukan kelompok peneliti untuk menghindari kemungkinan tertukar. Data yang diperoleh dalam penelitian ini berasal dari hasil pemeriksaan mikroskopis langsung pada sampel debu dan pengisian kuesioner faktor risiko. Selanjutnya data yang diperoleh dianalisis dengan menggunakan uji univariat untuk melihat distribusi frekuensi faktor risiko pada responden dan uji bivariat menggunakan uji chi-square untuk mengetahui hubungan faktor risiko dan keberadaan TDR. Penelitian telah mendapatkan persetujuan etik dari Unit Etika Penelitian Kedokteran / Kesehatan Fakultas Kedokteran Universitas Riau, Nomor: 215/UN.19.5.1.1.8/UEPKK/2019.

\section{HASIL}

\section{Karakteristik Responden Berdasarkan Jenis Kelamin dan Umur}

Karakteristik responden berdasarkan data demografi jenis kelamin dan umur dapat dilihat pada tabel 1 .

Tabel 1. Karakteristik responden berdasarkan jenis kelamin dan umur

\begin{tabular}{lll}
\hline Variabel & \multicolumn{2}{c}{ Jumlah } \\
\cline { 2 - 3 } 1. Jenis kelamin & $\mathrm{N}$ & $\%$ \\
Laki-laki & 36 & 51,4 \\
Perempuan & 34 & 48,6 \\
2. Umur & & \\
7-8 tahun & 22 & 31,43 \\
9-10 tahun & 27 & 38,57 \\
$>11$ tahun & 21 & 30 \\
\hline
\end{tabular}

Berdasarkan tabel 1, frekuensi jenis kelamin responden sebagian besar adalah laki-laki yaitu 36 orang $(51,4 \%)$ dan rentang umur terbanyak 9-10 tahun yaitu 27 orang $(38,57 \%)$ dengan rata-rata umur 10 tahun.

\section{Proporsi Tungau Debu Rumah pada Rumah Siswa SDN 001 Buluh Cina, Kecamatan Siak Hulu, Kabupaten Kampar, Provinsi Riau}

Hasil pemeriksaan sampel debu yang dilakukan di Laboratorium Parasitologi Fakultas Kedokteran Universitas Riau terhadap proporsi 
TDR pada rumah siswa SDN 001 Buluh Cina, Kabupaten Kampar, Provinsi Riau dapat dilihat pada tabel 2.

Tabel 2. Hasil Pemeriksaan Proporsi TDR

\begin{tabular}{ccc}
\hline Keberadaan TDR & N & $\mathbf{\%}$ \\
\hline Positif & 33 & 47,1 \\
Negatif & 37 & 52,9 \\
\hline Jumlah & 70 & 100 \\
\hline
\end{tabular}

Berdasarkan tabel 2, didapatkan proporsi positif TDR pada rumah siswa SDN 001 Buluh Cina, Kabupaten Kampar, Provinsi Riau sebanyak 33 orang $(47,1 \%)$.

\section{Gambaran Faktor Risiko Tungau Debu Rumah pada Rumah Siswa SDN 001 Buluh Cina, Kecamatan Siak Hulu, Kabupaten Kampar, Provinsi Riau}

Distribusi frekuensi faktor risiko TDR dapat dilihat pada tabel 3. Berdasarkan data dari tabel 3, didapatkan distribusi frekuensi faktor risiko TDR pada responden sebagian besar memiliki status rumah pribadi sebanyak $82,9 \%$, jenis lantai rumah keramik sebanyak $68,6 \%$, jenis tempat tidur berbahan non-alami sebanyak yaitu $65,7 \%$ kemudian luas ventilasi rumah baik sebanyak $75,7 \%$ dan frekuensi membersihkan tempat tidur baik sebanyak $54,3 \%$.

\section{Hubungan Keberadaan TDR dan Faktor Risiko pada Rumah Siswa SDN 001 Buluh Cina, Kabupaten Kampar, Provinsi Riau}

Hubungan keberadaan TDR dan faktor risiko dapat dilihat pada tabel 4. Berdasarkan tabel 4, setelah dilakukan uji statistik chi square didapatkan hubungan yang bermakna antara jenis tempat tidur dengan keberadaan TDR $(\mathrm{p}<0,05)$. Namun, tidak terdapat hubungan yang bermakna antara status rumah, frekuensi membersihkan tempat tidur, luas ventilasi rumah, dan jenis lantai rumah dengan keberadaan TDR $(p>0,05)$.
Tabel 3 Distribusi frekuensi faktor risiko TDR

\begin{tabular}{lcc}
\hline \multicolumn{1}{c}{ Faktor Risiko } & N & \% \\
\hline Status rumah & 58 & 82,9 \\
$\quad$ Pribadi & 12 & 17,1 \\
$\quad$ Kontrakan & & \\
Luas Ventilasi Rumah & 53 & 75,7 \\
$\quad$ Baik & 17 & 24,3 \\
$\quad$ Buruk & & \\
Jenis Lantai Rumah & 48 & 68,6 \\
$\quad$ Keramik & 22 & 31,4 \\
$\quad$ Non-keramik & & \\
Jenis Tempat Tidur & 55 & 78,6 \\
$\quad$ Non-alami & 15 & 21,4 \\
$\quad$ Alami & & \\
Frekuensi Membersihkan Tempat & & \\
Tidur & 38 & 54,3 \\
$\quad$ Baik & 32 & 45,7 \\
$\quad$ Buruk & & \\
\hline
\end{tabular}

\section{PEMBAHASAN}

\section{Karakteristik Responden Berdasarkan Jenis Kelamin dan Umur}

Karakteristik responden berdasarkan jenis kelamin, lebih banyak siswa laki-laki yaitu 36 orang $(51,4 \%)$ dibandingkan perempuan yaitu 34 orang $(48,6 \%)$. Hasil ini kemungkinan dikarenakan data jumlah siswa SDN 001 Buluh Cina sebagian besar laki-laki. Kemudian sebagian besar responden yang mengembalikan sampel debu pada penelitian ini adalah siswa laki-laki. ${ }^{14}$ Hasil ini sejalan dengan penelitian Subahar (2016) di Jakarta didapatkan responden laki-laki lebih banyak yaitu $52,27 \%$ dan responden perempuan $47,73 \%$. Subahar menyebutkan bahwa hal tersebut dikarenakan responden laki-laki memiliki perhatian lebih tinggi terhadap penelitian dibandingkan perempuan. ${ }^{15}$

Karakteristik responden berdasarkan umur pada penelitian ini terbanyak pada rentang umur 910 tahun 27 orang $(38,57 \%)$, kemudian umur $>11$ tahun 21 orang $(30 \%)$ dan umur 7-8 tahun 22 orang (31,43\%). Hasil ini kemungkinan dikarenakan jumlah sebaran data siswa terbanyak pada SDN 001 Buluh Cina adalah siswa kelas 3 dan 4 SD yang rata-rata berumur 9-10 tahun. Hasil ini sejalan dengan penelitian Mantu ${ }^{16}$ pada siswa 003 Buluh Nipis bahwa karakteristik 
Muhammad Kurnia Caesar dkk, Tungau Debu Rumah

Tabel 4. Hubungan Keberadaan TDR dan faktor risiko pada rumah siswa SDN 001 Buluh Cina

\begin{tabular}{|c|c|c|c|c|c|}
\hline \multirow{3}{*}{ Faktor Risiko } & \multicolumn{4}{|c|}{ Keberadaan TDR } & \multirow{3}{*}{ p value } \\
\hline & \multicolumn{2}{|c|}{ Positif } & \multicolumn{2}{|c|}{ Negatif } & \\
\hline & $\mathbf{N}$ & $\%$ & $\mathbf{N}$ & $\%$ & \\
\hline \multicolumn{6}{|l|}{ Status Rumah } \\
\hline - $\quad$ Pribadi & 30 & 51,7 & 28 & 48,3 & \multirow{2}{*}{0,091} \\
\hline - Kontrakan & 3 & 25,0 & 9 & 75,0 & \\
\hline \multicolumn{6}{|l|}{ Luas Ventilasi Rumah } \\
\hline - Baik & 23 & 43,4 & 30 & 56,6 & \multirow{2}{*}{0,268} \\
\hline - $\quad$ Buruk & 10 & 58,8 & 7 & 41,2 & \\
\hline \multicolumn{6}{|l|}{ Jenis Lantai Rumah } \\
\hline - Keramik & 26 & 54,2 & 22 & 45,8 & \multirow{2}{*}{0,082} \\
\hline - Non-keramik & 7 & 31,8 & 15 & 68,2 & \\
\hline \multicolumn{6}{|l|}{ Jenis Tempat Tidur } \\
\hline - Alami & 11 & 73,3 & 4 & 26,7 & \multirow{2}{*}{0,022} \\
\hline - Non-alami & 22 & 40,0 & 31 & 60,0 & \\
\hline \multicolumn{6}{|c|}{ Frekuensi Membersihkan Tempat Tidur } \\
\hline - $\quad$ Baik & 15 & 39,5 & 23 & 60.5 & 0,161 \\
\hline - $\quad$ Buruk & 18 & 56,3 & 14 & 43,8 & \\
\hline
\end{tabular}

umur terbanyak berada di rentang 9-10 tahun yaitu 40 orang $\left(57,9 \%\right.$.). Mantu ${ }^{16}$ menyebutkan bahwa hal tersebut dikarenakan responden yang mengembalikan sampel debu pada penelitian tersebut adalah siswa yang berumur 9-10 tahun.

\section{Proporsi Tungau Debu Rumah pada Rumah Siswa SDN 001 Buluh Cina Kabupaten Kampar Provinsi Riau}

Hasil penelitian yang dilakukan pada rumah siswa SDN 001 Buluh Cina, Kecamatan Siak Hulu, Kabupaten Kampar, Provinsi Riau didapatkan angka proporsi positif TDR sebanyak 33 rumah $(47,1 \%)$. Hasil ini meningkat dari penelitian tentang proporsi TDR di SDN 001 Buluh Cina didapatkan angka proporsi sebesar $40,3 \%{ }^{13}$ Angka proporsi TDR pada penelitian ini tergolong tinggi karena menurut Permenkes RI No. 1077 Tahun 2011, rasio positif TDR yang dikatakan tinggi yaitu $>35 \%{ }^{3}$ Tingginya angka proporsi TDR pada penelitian ini kemungkinan karena Desa Buluh Cina yang berada di dataran rendah dengan kelembapan udara tinggi yang cocok bagi perkembangbiakan TDR. ${ }^{7}$ Berdasarkan analisis faktor risiko sebagian besar responden memiliki status rumah pribadi $(82,9 \%)$ dan menggunakan jenis lantai keramik $(68,6 \%)$, hasil tersebut juga berpotensi meningkatkan angka proporsi TDR pada penelitian ini.

Penelitian ini sejalan dengan penelitian $\mathrm{Fia}^{17}$ di Kecamatan Tikala, Manado, didapatkan angka proporsi TDR yaitu 45,3\%. Menurut $\mathrm{Fia}^{17}$, hasil ini dikarenakan lokasi penelitian merupakan daerah dataran rendah dan sebagian besar responden memiliki perilaku sanitasi dan luas ventilasi rumah yang buruk. Penelitian ini tidak sejalan dengan penelitian yang dilakukan Widiastuti $^{8}$ di Pamulang didapatkan angka proporsi TDR yang tergolong rendah yaitu $28,1 \%$. Widiastuti8 menyebutkan bahwa rendahnya proporsi TDR pada penelitian tersebut dikarenakan sebagian besar responden pada penelitian tersebut memiliki perilaku kebersihan diri dan sanitasi yang baik.

Gambaran Faktor Risiko Tungau Debu Rumah pada Rumah Siswa SDN 001 Buluh Cina, Kecamatan Siak Hulu, Kabupaten Kampar, Serta Hubungannya

Hasil penelitian untuk analisis faktor risiko TDR pada rumah siswa SDN 001 Buluh Cina, Kabupaten Kampar, Provinsi Riau didapatkan sebagian besar responden memiliki status rumah pribadi $(82,9 \%)$, luas ventilasi baik $(75,7 \%)$, jenis lantai keramik $(68,6 \%)$, jenis tempat tidur nonalami $(78,6 \%)$ dan frekuensi membersihkan tempat tidur baik $(54,3 \%)$. 


\section{Status Rumah}

Hasil penelitian tentang faktor risiko status rumah didapatkan bahwa responden yang memiliki status rumah pribadi yaitu $82,9 \%$ dan kontrakan yaitu $17,1 \%$. Hasil ini menunjukkan bahwa sebagian besar responden memiliki tempat tinggal tetap di Desa Buluh Cina. Berdasarkan observasi peneliti, responden memiliki rumah pribadi karena telah menghuni rumah secara turuntemurun. Kemudian sebagian besar responden memiliki mata pencaharian sebagai nelayan dan petani sehingga mendorong responden untuk menetap di daerah tersebut. Berdasarkan hasil penelitian ini, sebagian besar responden dengan status rumah kontrakan (75\%) tidak ditemukan TDR di dalam rumah. Menurut teori, keberadaan TDR lebih sedikit ditemukan pada rumah kontrakan karena TDR akan terbawa oleh penghuni dan perabotan rumah ketika masa kontrak habis. Kemudian bahan makanan utama TDR yang berasal dari serpihan kulit manusia akan menyebabkan TDR mengikuti perpindahan penghuni ke tempat yang lain. ${ }^{5}$

Analisis hubungan faktor risiko dengan keberadaan TDR pada penelitian ini menunjukkan bahwa tidak terdapat hubungan yang bermakna antara status rumah dengan keberadaan TDR didapatkan $\mathrm{p}$ value sebesar 0,091 (>0,05). Hasil tersebut kemungkinan dikarenakan keberadaan TDR tidak hanya dipengaruhi oleh status rumah tetapi juga faktor risiko host dan lingkungan lainnya. Menurut teori, selain status rumah, terdapat aspek penting lain yang juga mempengaruhi keberadaan TDR seperti durasi menghuni rumah, perilaku kebersihan diri, dan sanitasi. ${ }^{5}$ Penelitian ini sejalan dengan penelitian Hayati $^{18}$ di Surabaya yang menyebutkan bahwa tidak terdapat hubungan yang bermakna antara status rumah dengan keberadaan TDR dengan $p$ value 0,219 $(>0,05)$. Hayati ${ }^{18}$ menyebutkan bahwa keberadaan TDR tidak hanya dipengaruhi oleh status rumah, tetapi juga dipengaruhi oleh beberapa faktor host seperti, kebiasaan mencuci tangan, kebiasaan menyapu ruangan, dan kebiasaan membersihkan tempat tidur.

\section{Luas Ventilasi Rumah}

Hasil penelitian faktor risiko luas ventilasi rumah pada rumah siswa SDN 001 Buluh Cina, Kabupaten Kampar, Provinsi Riau didapatkan luas ventilasi yang tergolong baik sebanyak 53 orang $(75,7 \%)$ dan buruk sebanyak 17 orang $(24,3 \%)$. Menurut pengamatan dan observasi, hasil ini kemungkinan dikarenakan tingkat pengetahuan responden yang baik tentang fungsi ventilasi dan luas ventilasi rumah minimal dalam menjaga kelembapan udara. Berdasarkan hasil penelitian ini, sebagian besar responden yang memiliki luas ventilasi baik $(56,6 \%)$ tidak ditemukan TDR di dalam rumah. Menurut teori, luas ventilasi yang baik yaitu $>10 \%$ dari luas lantai rumah dapat melancarkan sirkulasi udara dan mampu menjaga kelembapan udara di bawah $60 \%$ sehingga dapat mencegah perkembangbiakan TDR. ${ }^{15}$

Analisis hubungan faktor risiko dengan keberadaan TDR pada penelitian ini menunjukkan bahwa tidak terdapat hubungan yang bermakna antara luas ventilasi dengan keberadaan TDR didapatkan $\mathrm{p}$ value $0,268 \quad(>0,05)$. Hasil ini kemungkinan dikarenakan keberadaan TDR tidak hanya dipengaruhi oleh luas ventilasi tetapi juga faktor host seperti, perilaku kebersihan diri, sanitasi, dan jumlah penghuni rumah. Menurut Subahar ${ }^{15}$ menyebutkan bahwa selain luas ventilasi rumah, terdapat pula faktor host yang juga dapat mempengaruhi keberadaan TDR di dalam rumah seperti, perilaku kebersihan diri, sanitasi, dan jumlah penghuni rumah. Penelitian ini sejalan dengan penelitian Heriyani $^{20}$ di Banjarmasin yang menyebutkan bahwa tidak terdapat hubungan yang bermakna antara luas ventilasi dengan keberadaan TDR didapatkan $p$ value $0,23 \quad(>0,05)$. Menurut Heriyani ${ }^{20}$, hasil tersebut dikarenakan keberadaan TDR tidak hanya dipengaruhi oleh luas ventilasi rumah tetapi juga perilaku hygiene dan sanitasi responden. Heriyani menyebutkan pada rumah dengan ventilasi yang baik tetap ditemukan TDR dikarenakan perilaku hygiene dan sanitasi responden yang buruk.

\section{Jenis Lantai Rumah}

Hasil penelitian faktor risiko berupa jenis lantai rumah didapatkan responden yang menggunakan lantai keramik sebanyak 48 orang (68,6\%). Penggunaan lantai berjenis keramik masih umum digunakan karena mampu menyerap kalor dan memberikan suasana dingin di rumah. 
Lantai keramik juga sering digunakan karena faktor ketahanan bahan yang dapat digunakan dalam jangka waktu lama. Berdasarkan hasil penelitian ini, sebagian besar responden yang menggunakan jenis lantai keramik $(54,2 \%)$ ditemukan positif TDR di dalam rumah. Menurut teori, hal ini dikarenakan lantai keramik dapat menyerap kalor lebih baik sehingga meningkatkan kelembapan udara di dalam rumah. Kelembapan udara $>70 \%$ merupakan kondisi yang cocok bagi perkembangbiakan TDR. ${ }^{8}$

Analisis hubungan faktor risiko dengan keberadaan TDR pada penelitian ini menunjukkan bahwa tidak terdapat hubungan yang bermakna antara jenis lantai rumah dengan keberadaan TDR didapatkan $\mathrm{p}$ value 0,082 (>0,05). Hasil ini dikarenakan keberadaan TDR tidak hanya dipengaruhi oleh jenis lantai tetapi juga faktor host seperti perilaku kebersihan diri dan sanitasi. Menurut Kenneth (2017) ${ }^{21}$ menyebutkan bahwa selain faktor jenis lantai, terdapat beberapa faktor host seperti perilaku kebersihan diri dan sanitasi yang juga dapat mempengaruhi keberadaan TDR di dalam rumah. Kenneth ${ }^{21}$ juga menyebutkan bahwa responden dengan lantai non-keramik belum tentu dapat terhindar dari TDR jika memiliki perilaku kebersihan diri dan sanitasi yang buruk. Hasil penelitian ini tidak sejalan dengan penelitian Juniartha $^{22}$ di Denpasar yang menyebutkan bahwa terdapat hubungan yang bermakna antara jenis lantai rumah dengan keberadaan TDR dengan nilai $\mathrm{p}$ value $0,013 \quad(<0,05)$. Menurut Juniartha ${ }^{22}$, hasil tersebut dikarenakan $83 \%$ responden yang menggunakan jenis lantai keramik ditemukan positif TDR.

\section{Jenis Tempat Tidur}

Pada penelitian ini didapatkan responden yang menggunakan tempat tidur berbahan non-alami sebanyak 55 orang $(78,6 \%)$ dan berbahan alami sebanyak 15 orang $(21,4 \%)$. Hasil tersebut menunjukkan bahwa sebagian masyarakat menggunakan tempat tidur berbahan non-alami. Berdasarkan observasi peneliti, responden lebih banyak menggunakan tempat tidur dengan jenis nonalami karena harga yang murah dan cara perawatan yang praktis. Berdasarkan hasil penelitian ini, sebagian besar responden dengan jenis tempat tidur alami $(73,3 \%)$ ditemukan positif TDR di dalam rumah. Hal ini kemungkinan dikarenakan serat kapuk pada tempat tidur alami mengandung jamur (mold) yang dapat melembutkan kulit manusia sehingga menghasilkan serpihan kulit (detritus) lebih banyak. Detritus dalam jumlah besar akan menjadi komponen debu dan bahan makanan yang baik bagi TDR. Hal tersebut mengakibatkan TDR dapat berkembang biak secara optimal pada rumah responden yang menggunakan jenis tempat tidur alami yaitu kasur kapuk.

Analisis hubungan faktor risiko dengan keberadaan TDR pada penelitian ini menunjukkan bahwa terdapat hubungan yang bermakna antara jenis tempat tidur dengan keberadaan TDR didapatkan $\mathrm{p}$ value $0,022 \quad(<0,05)$. Hasil ini membuktikan bahwa jenis tempat tidur berperan penting dalam mempengaruhi keberadaan TDR di dalam rumah. Menurut teori rumah yang menggunakan jenis tempat tidur alami memiliki risiko 5 kali lebih besar ditemukan TDR dibandingkan jenis tempat tidur lainnya. ${ }^{9}$ Penelitian ini sejalan dengan penelitian Kariadi ${ }^{23}$ di Semarang dengan nilai $\mathrm{p}$ value $0,013(<0,05)$. Menurut Kariadi23, hasil tersebut dikarenakan $71,6 \%$ responden yang menggunakan tempat tidur alami atau kasur kapuk ditemukan positif TDR.

\section{Frekuensi Membersihkan Tempat Tidur}

Responden yang memiliki frekuensi membersihkan tempat tidur baik sebanyak 38 orang $(54,3 \%)$ dan buruk sebanyak 32 orang $(45,7 \%)$. Berdasarkan wawancara dan observasi, hasil tersebut didukung oleh pengetahuan orang tua siswa yang sudah baik tentang pentingnya rutinitas membersihkan tempat tidur. Berdasarkan hasil penelitian ini, sebagian besar responden dengan frekuensi membersihkan tempat tidur baik $(60,5 \%)$ tidak ditemukan TDR di dalam rumah. Menurut teori, Hal tersebut dikarenakan debu sebagai media hidup TDR akan terbuang pada tempat tidur yang rutin dibersihkan minimal 2 kali sehari. ${ }^{8}$

Analisis hubungan faktor risiko dengan keberadaan TDR pada penelitian ini menunjukkan bahwa tidak terdapat hubungan yang bermakna antara frekuensi membersihkan tempat tidur dengan keberadaan TDR didapatkan $p$ value 0,161 
$(>0,05)$. Hasil ini kemungkinan dikarenakan keberadaan TDR tidak hanya dipengaruhi oleh frekuensi membersihkan tempat tidur, tetapi juga beberapa faktor lingkungan seperti, luas ventilasi rumah, jenis lantai rumah, dan jenis tempat tidur. Menurut Subahar (2016) ${ }^{15}$ menyebutkan bahwa selain frekuensi membersihkan tempat tidur terdapat pula beberapa faktor lingkungan yang juga dapat mempengaruhi keberadaan TDR di dalam rumah seperti, luas ventilasi, jenis lantai rumah, dan jenis tempat tidur. Penelitian ini sejalan dengan penelitian Yudopranoto $(2013)^{24}$ di Semarang yang menyebutkan bahwa tidak terdapat hubungan yang bermakna antara frekuensi membersihkan tempat tidur dengan keberadaan TDR didapatkan $p$ value $0,71(>0,05)$. Menurut Yudopranoto $^{24}$, keberadaan TDR pada rumah responden tidak hanya dipengaruhi oleh frekuensi membersihkan tempat tidur, tetapi juga faktor lingkungan seperti, penggunaan kasur kapuk, suhu, dan kelembapan udara di dalam rumah.

\section{Keterbatasan Penelitian}

Sampel tungau yang digunakan dalam penelitian ini hanya dibagi dalam dua kategori yaitu positif dan negatif tanpa memperhatikan aspek kepadatan TDR. Karakteristik faktor host yang beragam dapat mempengaruhi hasil pada penelitian ini

\section{KESIMPULAN}

Berdasarkan hasil penelitian didapatkan proporsi TDR pada rumah siswa SDN 001 Buluh Cina, Kabupaten Kampar Provinsi Riau adalah 47,1\%. Gambaran faktor risiko pada responden sebagian besar memiliki status rumah pribadi $(82,9 \%)$, luas ventilasi rumah yang tergolong baik $(75,7 \%)$, lantai rumah berjenis keramik $(68,5 \%)$, jenis tempat tidur non-alami (78,5\%) dan frekuensi membersihkan tempat tidur yang tergolong baik $(54,3 \%)$. Terdapat hubungan yang bermakna antara faktor risiko jenis tempat tidur dengan keberadaan TDR ( $p$ value $<$ $0,05)$.

\section{DAFTAR PUSTAKA}

1. Baratawidjaja K. Alergi dasar. Edisi.10. Jakarta: Fakultas Kedokteran Universitas Indonesia; 2009; p.133-4

2. World Health Organization. Prevalence of house dust mites in eight different geographic areas. $\mathrm{J}$ Immune. 2012; p.44-5

3. Kementerian Kesehatan Republik Indonesia. Survei distribusi populasi tungau debu rumah di daerah Indonesia 2013. Jakarta 2014.

4. Dinas Kesehatan Provinsi Riau. Laporan data prevalensi tungau debu rumah di Kabupaten Kampar tahun 2014. Pekanbaru 2014.

5. Widiastuti M,. Prevalensi dan faktor risiko tungau debu Pamulang, Tangerang. Journal UPNVJ. 2016; 50(2):93-5

6. Wilson JM, Platts-Mills TAE. Home environmental interventions for house dust mite. J Allergy Clin Immunol Pract. 2018 ; 6(1):1-7.

7. Sánchez-Borges M, Fernandez-Caldas E, Thomas WR, Chapman MD, Lee BW, Caraballo L, et al. International consensus (ICON) on: Clinical consequences of mite hypersensitivity, a global problem. World Allergy Organ Journal. 2017;10(1):1-26

8. Howieson SG, Lawson A, McSharry C, Morris G, McKenzie E, Jackson J. Domestic ventilation rates, indoor humidity and dust mite allergens: are our homes causing the asthma pandemic? Build Tech Journal. 2016 ; 24(3):137-9

9. Walangare KR. Tungau debu rumah di Kelurahan Taas Kecamatan Tikala Kota Manado. e-Journal UNSRAT. 2013. 1(2), p.11-2

10. Regina $M$, Breving R. Tungau debu rumah yang ditemukan di Kelurahan Perkamil Kecamatan Paal 2 Kota Manado. EBiomedik J. $2013 ; 1(2)$. p. 1-3

11. Rambing M. Survei perilaku masyarakat terhadap populasi tungau debu rumah di kelurahan perkamil kecamatan paal 2 Kota Manado. J e-Biomedik 2013. 3(2), p.231-2

12. Dinas Kesehatan Kabupaten Kampar. Laporan data prevalensi tungau debu rumah di Kabupaten Kampar tahun 2017. Bangkinang 2017

13. Dinas Kesehatan Provinsi Riau. Identifikasi tungau debu rumah pada anak SDN di 
Kabupaten Kampar tahun 2014. Pekanbaru 2014.

14. Kementerian Pendidikan dan Kebudayaan. Data pokok pendidikan SD 001 Buluh Cina, Kabupaten Kampar, Provinsi Riau. Bangkinang; 2020.

15. Subahar R, Aulung A. Faktor risiko yang mempengaruhi populasi tungau debu rumah di pasar rebo jakarta. Jurnal e-Biomedik. 2016 May 19;10(1):122-5

16. Mantu F. Identifikasi dan proporsi tungau debu rumah di tempat tinggal sekolah dasar di Kabupaten Kampar. [Skripsi]. Pekanbaru. Universitas Riau; 2016

17. Fia F, Johan J. Proporsi tungau debu rumah di Indonesia. Journal UNT. 2016. p. 13

18. Hayati U, Kahtan MI, Fitriangga A. Perbandingan populasi tungau pada rumah pribadi dan kontrakan di sdn 001 ketabang, Surabaya. Jurnal Kesehatan Khatulistiwa. 2019. (3)2. p.55

19. Kementerian Kesehatan Republik Indonesia. Peraturan Menteri Kesehatan Republik Indonesia No. 1077 Tahun 2011 tentang Penanggulangan penyakit alergi. Jakarta 2011.
20. Heriyani F, Khatimah H. Hubungan kondisi ventilasi rumah dengan keberadaan tungau debu di wilayah puskesmas kelayan timur. ULM Journal. 2018. p.31

21. Kenneth K, Malalayang K, Manado K, Hohakay YA, Wahongan GJP, Bernadus JBB. Gambaran faktor lingkungan yang berperan pada rumah yang ditemukan tungau debu di Kota Manado. Jurnal e-Biomedik (eBm). 2017. $5(1):$ p. $1-3$

22. Juniartha SK, Hadi HMC. Pengaruh penggunaan lantai keramik pada rumah dengan kelembapan udara optimal dan tungau debu rumah. Journal Denpasar. 2013. p.32

23. Kariadi RS. Perbandingan proporsi tungau debu rumah pada penduduk yang menggunakan kasur kapuk dan non kapuk di Semarang. Journal UNAIR. 2019. p.10.

24. Yudopranoto K. Perbandingan populasi tungau debu rumah dengan perilaku sanitasi di perumahan PJKA Kelurahan Randusari Semarang Selatan Jawa Tengah. e-prints UNDIP. 2013. p.22 